\title{
SSinteza
}

Impact of Internet on Business Activities

\section{MODERN INFORMATION TECHNOLOGIES APPLICATION IN DESTINATION MANAGEMENT COMPANIES}

\author{
Vesna Spasić, Angelina Njeguš, Danijel Pavlović \\ Singidunum Univerzitet, Beograd, Srbija
}

\begin{abstract}
:
The Internet has caused major changes in the distribution channels in the tourism market, threatening traditional tourism intermediaries' activity. At the same time, a number of suppliers have got access to global tourism market and a chance to offer new products and experts' knowledge in more efficient way. Among them we can mention destination management companies (DMC) which have expert knowledge about the tourism destination. They specialise in organising and carrying out different programmes for tourists and MICE tourism service users. This paper will analyse the basic features of the business of DMC in Serbia. We will focus on the possibilities of improving their business based on application of new IT solutions.
\end{abstract}

\author{
Key words: \\ DMC, \\ MICE tourism, \\ Internet, \\ new IT solutions.
}

\section{INTRODUCTION}

Dynamic expansion of the Internet has caused revolution in tourism products creation and distribution process. Changes have especially emerged in the communication process with consumers. These changes caused a need for distribution channels adaption to new trends at the market. Competitions between various suppliers also become very intensive. All that implies it is of great important for all of them to constantly update and innovate their business models. Those innovations are followed with the use of new technology tools in order to become more competitive in the market.

Traditional intermediaries are now facing with the growing problems caused by the tendency of disintermediation at the tourism market. These negative trends have also been present recent years in Serbia. Within these market conditions, some travel agencies have tried to specialise their business in order to improve their market position. The growing number of travel agencies started to offer incoming services in Serbia (about 30 agencies according to National Tourism Organisation of Serbia) [11]. Some of these travel agencies operate as Destination Management Company offering MICE tourism services to domestic and foreign business travellers.

Despite growing academic interests for e-tourism and the highlighted importance for information and communication technologies use in tourism and travel, in recent years there has been little research about new technologies innovation and application in travel agencies' business in Serbia. This especially relates DMC sector.

\section{DESTINATION MANAGEMENT COMPANIES}

According to the Association of Destination Management Executives (ADME), a Destination Management Company (DMC) is a professional service company that possess extensive local knowledge, expertise and resources, and is specialized in design, and implementation of events, activities, tours, transportation and program logistics [9]. The basic feature of DMC is expert knowledge of the destination and that gives them advantages in creating and organizing programs for leisure and corporate clients [3]. Compared to other intermediaries, DMC provide several advantages for their partners:

- One contact and payment for several services from different providers at the destination;

- Knowledge, experience and on-going relationships with the finest local venues, restaurants, transportation and other providers and possibility to obtain the best quality, service, prices etc.;

- Creative ideas for planning different types of events;

- Value-added services such as program design, logistics and supplier management, accounting etc.

It is very important for DMC to collaborate with public sector at destination, such as CVB (Convention and Visitors Bureau) or DMO (Destination Management Organisation). Public sector has the main role in promoting destination, and especially big international events. The collaboration with other intermediaries at the destination is necessary in order to provide an overall experience for customers. 
The most important clients for DMC are outgoing tour operators, travel agencies and meeting planners [3]. Although the leisure clients can be important for DMC, in this paper we will emphasise the role of MICE tourism for DMC business in Serbia. The market competition and the need for finding profitably segments have influenced on primary DMC's specialisation for corporate clients in our country.

\section{MICE TOURISM AND ADVANTAGES FOR DMC'S IN SERBIA}

MICE tourism (Meetings, Incentives, Conferences and Exhibitions) is complex of various activities including conventions, trade shows, seminars, events, exhibitions, incentive travel, as well as individual business travellers as a fast growing and lucrative segment of the tourism industry. The important effects are connected with the fact that MICE tourism could take place any time of the year, with the mild seasonality during May-June and September-October for big business events. Because of these reasons, there are a lot of positive effects on the tourist destination economy.

Business travellers, especially foreign visitors, are very important for Serbian tourism. MICE tourism in Serbia is based on relatively developed capacities (hotels, venues for meetings and conventions) concentrated mostly in Belgrade and Novi Sad. Tourism Strategy of the Republic of Serbia emphasis MICE tourism as "quick wins" products with the possibilities for reaching positive results in relatively short period. Some benefits from development of this type of tourism in Serbia are: [8]

- Business tourists spend 2 to 3 times more money than other tourists;

- MICE tourism activities are organised all over the year and create jobs with less seasonal character than the other types of tourism products;

- Inflow of foreign exchange in the case of foreign business travellers etc.

The basic characteristic of MICE tourism products in Serbia indicate possibilities for good positioning at domestic and international markets. Very intensive competition between numerous destinations at the international tourism market indicates the importance for large marketing activities, especially for Serbian Convention Bureau. MICE tourism is important for tourism destination image, and it's usually related with so called „leisure extensions to business trips".

Usually, this type of tourism covers a large group of tourists that are brought together for a particular purpose. Development of a well-planned agenda by the event organisers is important for the most of the activities included in MICE tourism. It evolves hosting, management and promotion of networking tourism businesses with other businesses (B2B) and also promotion of tourism businesses with consumers (B2C).

Numerous stakeholders are involved in creating products of MICE tourism. This type of tourism is usually arranged by intermediaries (Fig. 1), such as professional conference organisers, incentive travel agencies, and venue finding companies, destination management companies and other. The customer in the MICE sector can be a corporate company, non-profit organisation, association, government, academic institution, or SMERF travelling groups (Social, Military, Educational, Religious, Fraternal, indicating a market segment for the sales of banqueting rooms and meeting facilities). Suppliers are hotels, restaurants, transport companies, venues, audiovisual companies, food and beverage companies and other service providers.

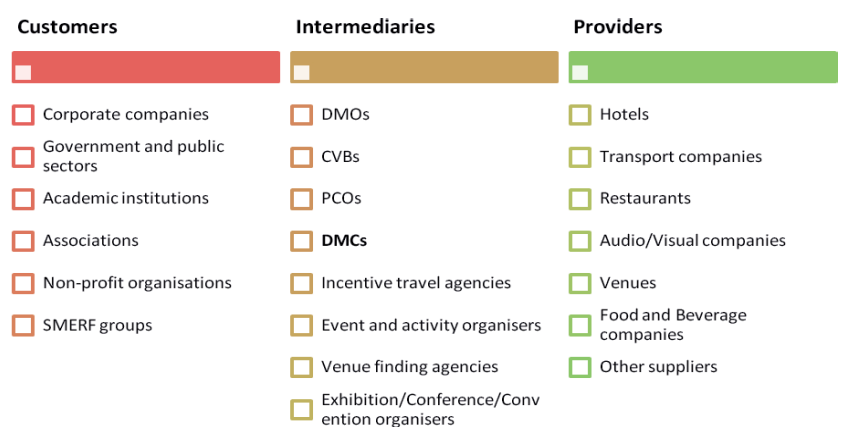

Figure 1. MICE tourism stakeholders

Further in this paper we will analyse the main feature of DMC's in Serbia and the level of information and communication technologies implementation in their business in recent years.

\section{RESEARCH: INFORMATION AND COMMUNICATION TECHNOLOGIES APPLICATION IN DMC'S IN SERBIA}

\section{Methodology of research}

Guided by the research goals in this paper, a survey was conducted via an online questionnaire. The questionnaire contained questions about the level of Information technology use in the DMC in Serbia.

For the purposes of this research, 16 DMC were selected. A criterion for selection of these travel agencies is based on data provided from Serbia Convention Bureau web site. Selected agencies are officially recognized by Serbia Convention Bureau as DMC in Serbia [10]. The answers were obtained from 8 companies which make $50 \%$ of sent questionnaires. Selected samples websites analysis revealed that the two agencies, that haven't fulfilled the questionnaire, have not fully functional website ("website is under construction"). Based on the results of studies, it can be assumed that these $8 \mathrm{DMC}$ are more advanced in the field of information technologies use. According to this, we conclude that answers are received from representative agencies in the DMC business in Serbia.

\section{Survey results}

The result of a survey indicates the following:

- The largest number among the DMC respondents operates over $5(38 \%)$ and $10(38 \%)$ years on the market. Two of the companies operate under the 5 years; 
- Number of employees in these DMC is lower than 10 so they are generally small agencies with a small number of employees;

- Analysis of the number of service users in 2013 is shown in the Table 1.

TABLE 1. The service user's number in 2013

\begin{tabular}{|l|c|}
\hline 500 service users & $25 \%$ \\
\hline From 501 to 1000 service users & $25 \%$ \\
\hline From 1001 to 2000 service users & $13 \%$ \\
\hline over 2000 service users & $38 \%$ \\
\hline
\end{tabular}

- These companies are mostly oriented to domestic clients $(63 \%$ of respondents marked that the domestic customers are predominant users of services, while $37 \%$ marked that they are mostly oriented to international clients).

Information obtained from the survey questions relating to the use of information technology in business indicates the following:

- Survey results of information technology usage in promotion point out that $50 \%$ of respondents use mainly traditional "tools" to promote their products/services (fairs, advertising, etc.) while the other half uses electronic media (websites, portals, banners etc.)

- $63 \%$ of surveyed DMC's use information technologies in sales operations (accepting queries, requests for service reservation, etc.) while $37 \%$ are selling products/services on traditional way.

- Business relationship with service providers or suppliers that provide needed services for DMC companies in Serbia (hotels, congress centres, rent-acar companies, restaurants, etc.) are mostly based on traditional cooperation (traditional contracting) (37\%). Used tools are shown in Figure 2.

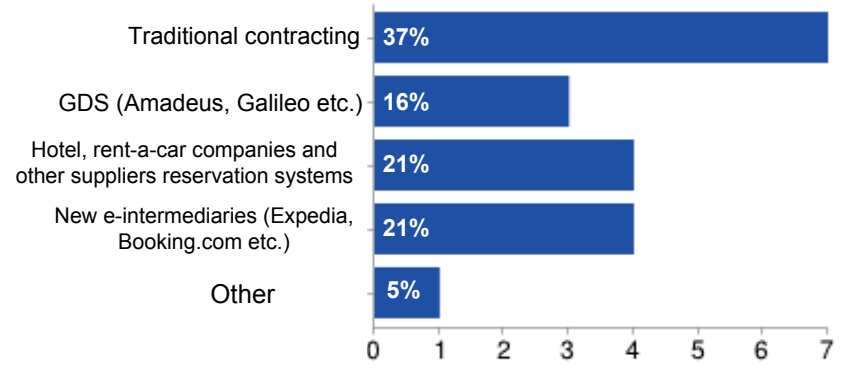

Figure 2. Providing the necessary capacities in relation with suppliers

Seven DMC have marked they use traditional ways for providing facilities from suppliers. Global distribution systems are used in percentage of $16 \%$ ( 3 agencies). Supplier's reservation systems use $21 \%$ of agencies. The same percentage use new electronic intermediaries (4 agencies). It should be noted that the agencies are mainly oriented to more than one of the shown ways for providing necessary capacity. So, answering the questionnaire an agency could select more than one provided answers (Fig. 2.).
Respondents indicated that they use Information technologies for selling the product and also for promotion. Answers received are implying they use technologies that are on a "basic" level (websites, portals, reservation systems etc.) for online payment and registration, client tracking and promotion. Most of DMC's (75\%) indicated that they are planning innovations trough new information technologies implementation, while $25 \%$ of respondents feels that they do not need innovations.

According to the results of a research in the next chapter a recommendations for information technologies innovations for Serbian DMC's will be presented.

\section{THE IMPACT OF INFORMATION TECHNOLOGY ON DMC BUSINESS - RECOMMENDATIONS FOR SERBIAN DMC'S}

The Internet has become an important trade channel, since around $60 \%$ of trade and professional associations use the Internet to look for information and decide on MICE venues [2]. Modern technologies bring instant, personalised and bookable services (Fig. 2).

Customer technology is changing traveller's behaviour and expectations. Web 3.0 services are becoming more intelligent, personalised, location-based, accessible, available with real-time information, easier to use etc. Customers are more keen to use systems that contain features, such as customisation of services, freedom of choice, scrutinise (customer will check it out before he buy it), integrity, collaboration, entertainment, speed and innovation [4].

DMC tries to keep up with the latest advancements focusing on cost optimisation, performance enhancement, and service personalisation according to customer's needs. Today, DMC needs an integrated and intelligent destination management system (DMS) to support, facilitate, and enhance businesses with customers and providers.

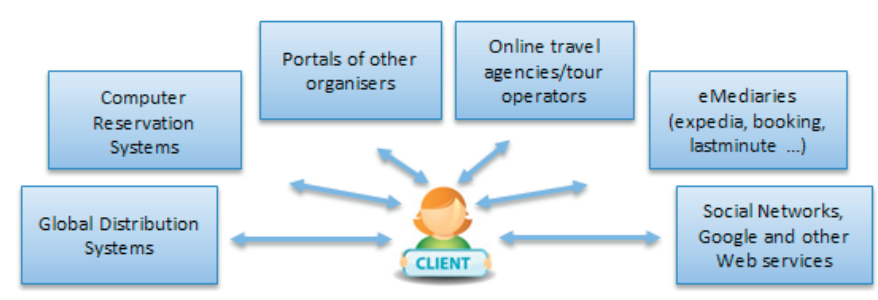

Figure 3. Customer's info and booking sources for MICE request

\section{Destination Management Information System}

Destination Management System (DMS) is not just a website, or content management system or online booking system. It consolidates and distributes a comprehensive range of tourism products through a variety of channels and platforms, and supporting the activities of a DMC [5]. DMS can be seen as an integration of three different systems:

1. Internal DMC business system - integrates all DMC business activities, such as promotional activities, event planning and management, financial management, market research and analysis, direct 
mail and email campaigns, human resource management etc.

2. Customer Relationship Management systems (CRM) - information search, customer service and support, contact management, collaboration solutions, reservations, customer intelligence etc.

3. Providers' service management systems (B2B).

Typical DMS modules are Destination Content Management System, Event Management Services, Dynamic Packaging, Geographic Information System, Marketing Information System, Management Information Systems, Risk Management, and Customer Relationship Management etc. All of these modules should be based on centralized database. If that is not the case, applications have their own databases (or are acquired from different vendors), than they should be integrated via a service bus. Centralized service buses facilitate interoperability of different applications across platforms and enhance communication within the existing infrastructure (Fig. 5). Considering that providers' services are changing over a time, DMS should be integrated with providers' information systems, too. This allows users to have access to real-time and updated data.

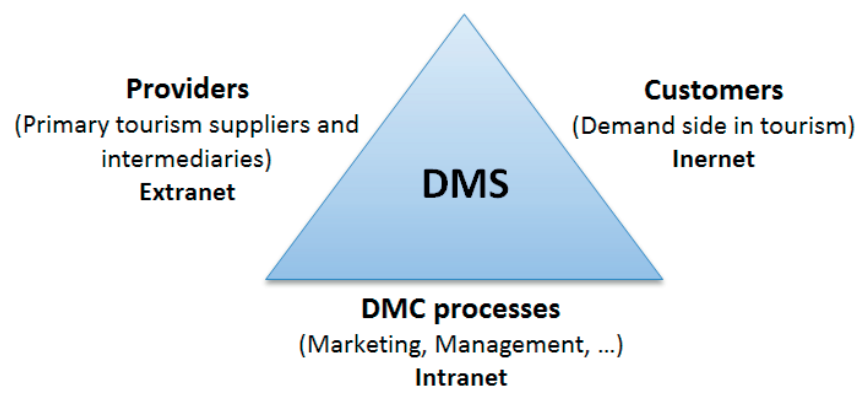

Figure 4. DMS modules [7]

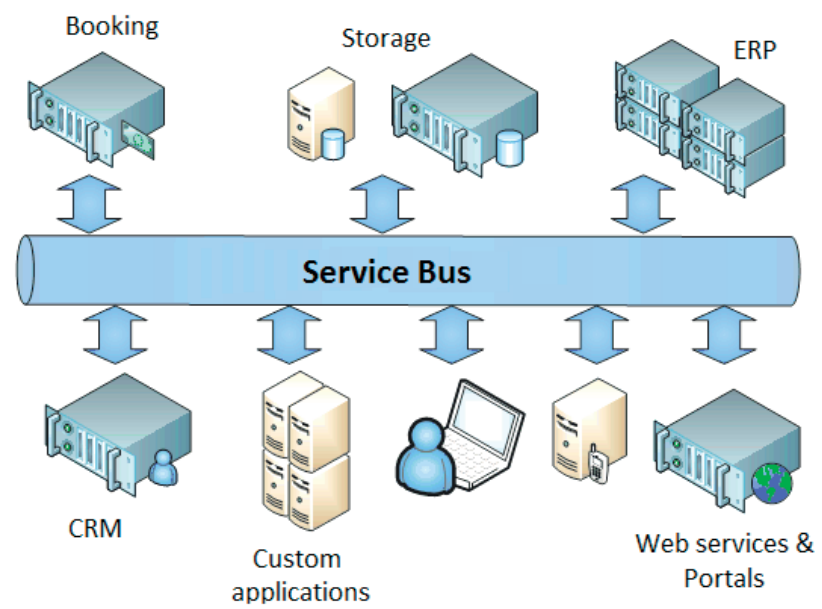

Figure 5. Application integration via a service bus [6]

\section{MICE Management System providers}

Today, DMC could develop customized DMS system or buy several applications and integrate them via a service bus. Some systems are:

- Active Conference - Cloud based Event Management Software by Active Network Business Solutions (www.activeevents.com/solutions/product/ active-conference)

- Mobile Applications for Events and Meetings - by Cvent Solutions (http://www.cvent.com/en/mobile-event-apps)

- EventsPro - Event Management Software by Centium Software (www.centiumsoftware.com/eventspro/event-management-tools.html)

- Destination Management Systems by New Mind (www.newmind.co.uk)

- Micefinder.com by MICEFINDER (www.micefinder.net)

- OpenConf - Peer-Review, Abstract and Conference Management tool (www.openconf.com).

Some features of these solutions are:

- Contact Management

- Accommodation

- Travel and transport

- Registration

- Online Forms and Web Content

- Attendee Management Solutions

- Event Marketing Tools

- Financials and Reports

- Online Event Reports

- Mobile Event Management

- Speaker and Exhibitor Resource Center

- Professional Services

There are several vendors that develop systems for MICE as shown. However, there are no an integrated DMS, as described earlier.

\section{CONCLUSION}

Although insufficiently investigated, the use of information technology in DMC's business open wide opportunities for business improvement. It may prove to be efficient and effective, particularly in MICE tourism. Examples, shown by the results of a research in Serbia, indicates that the use of new technology solutions in the DMC business is not yet at the level of features that existing information technologies can offer. It is necessary for DMC's in Serbia to keep track with innovations in order to improve their own businesses. Also those improvements supports the MICE tourism promotion and distribution as "quick wins" product with the possibilities for reaching positive results in relatively short period with a positive effects on the tourist destination economy.

\section{REFERENCES}

[1] Buhalis, D. and Licata, M., C., (2002) The Future eTourism intermediaries Tourism Management, 23. pp. 207-220. epubs.surrey.ac.uk/1126/1/fulltext.pdf

[2] CBI (2012), Meetings, Incentives, Conferences, Exhibitions (MICE) in the UK. Centre for the Promotion of Imports from developing countries (CBI) - Ministry of Foreign Affairs. Available at: http://www.cbi.nl/system/files/marketintel/Meetings_Incentives_Conferences_Exhibitions_MICE_ in_the_UK.pdf 
[3] Destination Management Company Training Manuel for USAID - pdf.usaid.gov/pdf_docs/PNADL944.pdf

[4] Eftekhari, M. H., Barzegar, Z. and Isaai, M. T. (2010). Web 1.0 to web 3.0 evolution: reviewing the impacts on tourism development and opportunities. Lecture Notes in Computer Science, pp: 184-193.

[5] Frew, A.J. and Horan, P (2007) Destination Website Effectiveness - A Delphi Study-based eMetric Approach, Proceedings of the Hospitality Information Technology Association Conference, HITA 07, Orlando, USA..

[6] Hansen, D. (2008) Blueprint for Successful SOA Integration. Oracle.
[7] Jovanovic, V., Njegus, A. (2013) The Use of GIS in Tourism Supply and Web Portal Development. International Journal on Information Technology (IREIT). 1(5). Praise Worthy Prize.

[8] Horwath Consulting Zagreb, Faculty of Economics, Belgrade University, (2005)Tourism Strategy of the Republic of Serbia, Ministry of Trade, Tourism and Services.

[9] www.adme.org/dmc/what-is-a-dmc.asp

[10] www.cvbs

[11] www.serbia.travel

[12] www.ttgmena.com/future-trends-in the tourism-industry/ 08 